\section{СТАТИСТИКА, ЕСЕП ЖӘНЕ АУДИТ}

\section{СТАТИСТИКА, УЧЕТ И АУДИТ}

\section{STATISTICS, ACCOUNT AND AUDIT}

ISSN 1563-2415

Ежеквартальный научнопрактический журнал издается с 1999 года.

№ 1(84) 2022

Учредитель «Алматинский гуманитарно-экономический университет»

Алматинский гуманитарно-экономический университет

Главный редактор

Досаева С.К.

Заместители гл. редактора:

Корвяков В.А. - д.п.н., проф., ректор АГЭУ

Сейтхамзина Г.Ж. - к.э.н., проф., проректор по науке и инновациям АГЭУ

\section{Члены редколлегии:}

Амирханова Г.А. - доктор $\mathrm{PhD}$, снс ИИВТ КН МОН РК, г.Нур-Султан, Казахстан

Бекенова Л.М. - к.э.Н., профессор, проректор по академической работе АГЭУ

Дауренбеков А.К. - к.э.н., проф. АГЭУ, г. Алматы, Казахстан

Дырка Стефан - д.э.н., проф., Верхнесилезский экономический Университет имени Вой- цеха Корфанти в Катовицах, Польша

Ерж⿻анов М.С. - д.э.н., проф., партнер «Grant Thornton», г.Алматы, Казахстан

Ешпанова Д.Д. - к.э.н., доцент кафедры "Учет, аудит и статистика" АГЭУ, г.Алматы, Казахстан

Макыш С.Б. - д.э.н., проф., декан экономического факультета, ЕНУ им.Л.Н.Гумилева, г.Нур-Султан, Казахстан

Мезенцева T.M. - д.э.н., профессор департамента учета, анализа и аудита Финансового Университета при правительстве РФ, г.Москва, Россия

Назарова В.Л. - Д.э.н., проф., зав. кафедрой "Учет, аудит и статистика" АГЭУ, г.Алматы, Казахстан

Рахметова P.У. - д.э.н, проф., Туран - Астана, Нурсултан, Казахстан

Сейдахметова Ф.С. - д.э.н., проф. кафедры "Учет, аудит и статистика" АГЭУ, г.Алматы, Казахстан

Taunoв T.A. - к.э.н., проф., АГЭУ, г.Алматы, Казахстан

Тайгашинова К.T. - д.э.Н., проф кафедры "Учет, аудит и статистика", АГЭУ, г.Алматы, Казахстан

Шокаманов Ю.К. - Д.э.н., проф., г.Нур-Султан, Казахстан

\section{Издательский центр}

Алматинского гуманитарно-

экономического университета

050035, г.Алматы,

ул.Жандосова, 59,

тел: +7 7273095820 ,

$+77273095815$

факс: + 77273093000

e-mail: zhurnal.aesa.99@mail.ru

www.journal.ageu.kz, www.ageu.kz

Ответственный за выпуск журнала Айтжанова Н.M.

Подписано в печать: 26.01.2022г.

Формат 70x108 1/16.

Бумага офсетная.

Тираж 300 экз.

\section{ИП «Аруна»}

г.Алматы, Алмалинский район, ул. Нурмакова, 26/195 кв. 49 e-mail: mail: iparuna@yandex.ru 
ISSN 1563-2415

Учреждение «Алматинский гуманитарно-экономический университет», 050035, г. Алматы, ул. Жандосова, 59, тел.(727) 309-58-20, 309-58-15, вн. 138 e-mail: zhurnal.aesa.99@mail.ru, aesa2005@mail.ru

Website: journal.ageu.kz, www.ageu.kz

Регистрационное свидетельство № 9099-Ж от 25.03.2008 г. выдано Министерством культуры и информации Республики Казахстан, Комитетом информации и архивов

Журнал включен в Российский индекс научного цитирования (РИНЦ) и размещается в научной электронной библиотеке (WWW.ELIBRARY.RU) (Лицензионный договор с ООО «НЭБ» № 133-03/2016 г.Москва 11 марта 2016 г.). 
Раман Ибрахим, Сюзана Бахарудин

МЕЛИМАУ ПОЛИТЕХНИКАЛЫҚ ИНСТИТУТЫНДА КОВИД-19

ПАНДЕМИЯСЫ КЕЗІНДЕ СИНХРОНДАЛҒАН ОНЛАЙН ОҚЫТУҒА

КЕНЕТ ӨТУ: ИНЖЕНЕРЛІК ФАКУЛЬТЕТІ СТУДЕНТТЕРІ

ПЕРСПЕКТИВАСЫН САНДЫК ЗЕРТТЕУ ...

Нориымах Осман

4IR ЭЛЕМЕНТТЕРІН ҚОЛДАНУ АРҚЫЛЫ ТЖКБ ЦИФРЛАНДЫРУ.

Тан Си Мин

ЦИФРЛІК МІНЕЗ-ҚҰЛЫҚТЫ ДАМЫТУ ЖӘНЕ МУЛЬТИФИКАЦИЯ МЕН ИННОВАЦИЯЛЫҚ ОҚЫТУ ҚҰРАЛЫ РЕТІНДЕ ИНТЕГРАЦИЯЛАУ:

ОҚУДАҒЫ СТУДЕНТТЕРДІН МІНЕЗ-ҚҰЛҚЫНА ӘСЕРІ.

\section{Тео Пей Киан}

ӨНДІРІСТІК СТУДЕНТТЕРДІ ОҚУ ТИІМДІЛІГІНЕ ОҚУ

ИННОВАЦИЯЛАРЫНЫҢ ӘСЕРІ ЖОҒАРЫ ОҚУ ОҚУЫНДАҒЫ

ДИЗАЙН.....

Дви Вахюнинсси, Сламет Утомо, Шри Сурачми, Сажида Досаева

КОВИД-19 ПАНДЕМИЯСЫ КЕЗІНДЕ ОНЛАЙН ОҚЫТУДЫН САПАСЫН

АРТТЫРУДАҒЫ КӨШБАСШЫНЫН РӨЛІ.

А.Адельбаева, А. Бекметова

АЗЫҚ-ТҮЛІКПЕН МОЛЫҚТЫРУДЫ ҚАМТАМАСЫЗ ЕТУ ҮШІН

АГРАРЛЫҚ НАРЫҚТЫ РЕТТЕУ.

А. Джумабаева, Д. Бабаш, А.Кенджасарова, Р.Арзикулова

ҚАЗАҚСТАННЫН АЗЫҚ-ТҮЛІК ҚАУІПСІЗДІГІН ҚАМТАМАСЫЗ ЕТУ:

ТЕОРИЯ, ӘДІСТЕМЕ ЖӘНЕ ПРАКТИКА

А. Нуртаева, С. Айткулова, А.Садвакасова, А.Кұрмантаева

КОММЕРЦИЯЛЫҚ БАНКТЕРДЕГІ ТӘУЕКЕЛДЕРДІ БАСҚАРУ ЖҮЙ-

ЕСІНІН ТИІМДІЛІГІН ТАЛДАУ.

\section{А.Рамазанов, С.Базылхан}

ҚОНАҚЖАЙЛЫЛЫҚТЫН КОНЦЕПТУАЛДЫҚ НЕГІЗДЕРІ.

А.Рамазанов, Ж.Куралов

ҚОНАҚ ҮЙ ІСІНІҢ ЭКОНОМИКАЛЫҚ СИПАТТАМАСЫ.

II.A. Topzaeвa

КОМПАНИЯ ҚЫЗМЕТІНДЕГІ ИНТЕРНЕТ МАРКЕТИНГ 


\section{СОДЕРЖАНИЕ}

Раман Ибрагим, Сюзана Бахарудин

ВНЕЗАПНЫЙ ПЕРЕХОД К СИНХРОНИЗИРОВАННОМУ ОНЛАЙНОБУЧЕНИЮ ВО ВРЕМЯ ПАНДЕМИИ COVID-19 В ПОЛИТЕХНИЧЕСКОМ ИНСТИТУТЕ МЕРЛИМАУ: КОЛИЧЕСТВЕННОЕ ИССЛЕДОВАНИЕ ПЕРСПЕКТИВ СТУДЕНТОВ ФАКУЛЬТЕТА МАШИНОСТРОЕНИЯ.............. 6

Норшыммах Осман

ОЦИФРОВКА ТVЕТ С ИСПОЛЬЗОВАНИЕМ ЭЛЕМЕНТОВ 4IR.

Тан Си Мин

РАЗРАБОТКА ЦИФРОВОГО ПОВЕДЕНИЯ И ИНТЕГРИРОВАНИЕ С МУЛЬТИФИКАЦИЕЙ В КАЧЕСТВЕ ИННОВАЦИОННОГО УЧЕБНОГО СРЕДСТВА: ВЛИЯНИЕ НА ПОВЕДЕНИЕ УЧАЩИХСЯ В ОБУЧЕНИИ.......

\section{Тео Пей Киан}

ВЛИЯНИЕ ОБУЧАЮЩИХ ИННОВАЦИЙ НА ЭФФЕКТИВНОСТЬ ОБУЧЕНИЯ СТУ ДЕНТОВ ПРОМЫШЛЕННЫХ ДИЗАЙН В ВЫСШЕМ ОБРАЗО-

ВАНИИ.

Dwi Wahyuningsih, Slamet Utomo, Sri Surachmi, Сажида Досаева

РОЛЬ РУКОВОДИТЕЛЯ В ПОВЫШЕНИИ КАЧЕСТВА ОНЛАЙН-

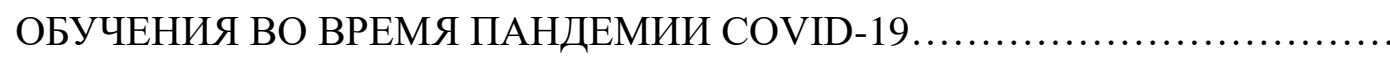

А.Адельбаева, А.Бекметова

РЕГУЛИРОВАНИЕ АГРАРНОГО РЫНКА ДЛЯ ОБЕСПЕЧЕНИЯ ПРОДО-

ВОЛЬСТВЕННОГО НАСЫЩЕНИЯ.

А. Джумабаева, Д. Бабаш, А.Кенджасарова, Р. Арзикулова ОБЕСПЕЧЕНИЕ ПРОДОВОЛЬСТВЕННОЙ БЕЗОПАСНОСТИ КАЗАХСТАНА: ТЕОРИЯ, МЕТОДОЛОГИЯ И ПРАКТИКА.

А. Нуртаева, С. Айткулова, А.Садвакасова А. Құрмантаева

АНАЛИЗ ЭФФЕКТИВНОСТИ СИСТЕМЫ УПРАВЛЕНИЯ РИСКАМИ В КОММЕРЧЕСКИХ БАНКАХ

\section{Рамазанов А., С.Базылхан}

КОНЦЕПТУАЛЬНЫЕ ОСНОВЫ ГОСТЕПРИИМСТВА.

Рамазанов А., Ж.Куралов

ЭКОНОМИЧЕСКИЕ ХАРАКТИРИСТИКИ ГОСТИНИЧНОГО ДЕЛА.

U.A Торгаева

ИНТЕРНЕТ - МАРКЕТИНГ В КОМПАНИЯХ 


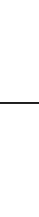

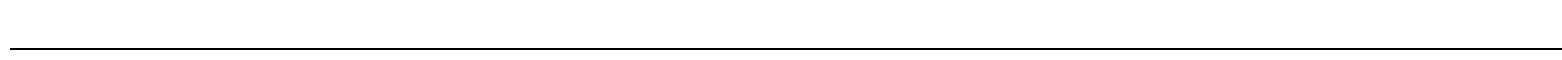

\section{Raman Ibrahim, Suzana Baharudin}

THE SUDDEN TRANSITION TO SYNCHRONIZED ONLINE LEARNING DURING THE COVID-19 PANDEMIC IN POLITEKNIK MERLIMAU: A QUANTITATIVE STUDY EXPLORING MECHANICAL ENGINEERING STUDENT'S PERSPECTIVES.

Norshymah Osman

DIGITALIZING TVET USING 4IR ELEMENTS.

Tan Si Min

DEVELOP DIGITAL STORYTELLING INTEGRATES WITH ANIMATION AS AN INNOVATIVE INSTRUCTIONAL TOOL: EFFECTS ON STUDENT'S BEHAVIOURAL ENGAGEMENT IN LEARNING.

Teo Pei Kian

THE EFFECT OF TEACHING INNOVATION ON LEARNING EFFECTIVENESS AMONG THE STUDENTS OF INDUSTRIAL

DESIGN IN HIGHER EDUCATION

Dwi Wahyuningsih, Slamet Utomo, Sri Surachmi, Sazhida Dossayeva

THE ROLE OF THE PRINCIPAL IN IMPROVING THE QUALITY OF ONLINE LEARNING DURING THE COVID-19 PANDEMIC

A. Adelbaeva Phd student, A. Bekmetova

REGULATION OF THE AGRICULTURAL MARKET TO ENSURE FOOD SATURATION

A. Dzhumabayeva, D. Babash, A. Kendzhasarova, R.Arzikulova

ENSURING FOOD SECURITY IN KAZAKHSTAN: THEORY, METHODOLOGY AND PRACTICE.

A. Nurtayeva, S. Aitkulova, A.Sadvakassova, A. Kurmantaeva

ANALYSIS OF THE EFFECTIVENESS OF THE RISK MANAGEMENT SYSTEM IN COMMERCIAL BANKS

Ramazanov A., C. Bazylhan

CONCEPTUAL BASIS OF HOSPITALITY.

Ramazanov A., Zh. Kuralov

ECONOMIC CHARACTERISTICS OF THE HOTEL BUSINESS

Torgaeva Sh.A

INTERNET MARKETING IN COMPANIES. 
Статистика, учет и аудит, 4(84)2022 стр. 61 - 67

\author{
МРНТИ 68.75.01 \\ УДК 631.1 \\ https://doi.org/10.51579/1563-2415.2022-1.06
}

\title{
REGULATION OF THE AGRICULTURAL MARKET TO ENSURE FOOD SATURATION
}

*A. Adelbaeva ${ }^{1}$, A. Bekmetova ${ }^{2}$

1. Kazakh National Pedagogical University named after Abay, Almaty, Kazakhstan

${ }^{2}$ Kazakh National University named after al-Farabi, Almaty, Kazakhstan

*e-mail:derzkiy.maga@mail.ru

\begin{abstract}
Annotation. The main task of the agricultural sector of Kazakhstan is to provide its population with food at the expense of its own production. The Republic has a high potential for dynamic growth and development. In the last two decades (2000-2020), the agriculture of the republic has been steadily developing. Growth in individual products is observed from $30 \%$ to 2.7 times. The number of livestock has increased by 1.5 to 2.5 times, depending on its type. All this contributed to a significant improvement in the food supply of the country's population compared to 2000-2010. However, for a number of products, especially potatoes, vegetables and fruits, milk, poultry meat and eggs, it was not possible to achieve or even approach scientifically sound nutrition standards. The share of imports for individual products remains high and exceeds the threshold level of $20 \%$ of imports in the capacity of the domestic market. The main reason is the insufficient level of agricultural production. Crop yields and livestock productivity remain low. Low labor productivity in the industry (7-8 thousand dollars) compared to developed countries (50-60 thousand dollars).
\end{abstract}

Keywords: agro-industrial complex, economy, development, food security, product quality, food, agriculture.

The main reasons for this situation are: reduction of soil fertility. Annual losses of humus in agriculture in Kazakhstan amount to 0.5-1.4 t/ha; poor material and technical equipment of commodity producers ( $70 \%$ of agricultural machinery is subject to replacement), which leads to massive technological disruptions. The fragmentation and small-scale production of agricultural subjects, their low payment capacity; insufficient degree of processing of agricultural products affects; the relatively low level of state support for the agricultural sector (4.5-5\% of the value of gross agricultural output, at the same time, according to WTO rules, $8.5 \%$ is allowed for the Republic of Kazakhstan). The development of agricultural cooperation and its financial support from the state are lagging behind. Together, all this determines the insufficient level of food security in Kazakhstan and causes the need for its assessment and development of improvement measures, which reflects the relevance of this article [1].

Main provisions of the article.

In developed countries with a high standard of living, the demand for food is quite high, and therefore the elasticity of demand for food prices is low.

In countries with a lower standard of living for people with low incomes, the elasticity of demand for the price of certain types of food, for example, meat, is quite high.

Despite the increase in prices for bakery and pasta products, their share in the total demand for food in Kazakhstan has increased, as prices for meat and meat products have also 


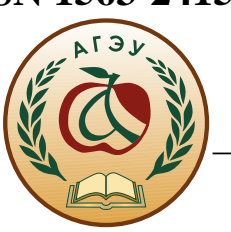

increased. In this regard, it is necessary to comprehensively address the issues of food security by improving the agricultural market.

Introduction. In the Message of the Head of State K.-Zh. Tokayev to the people of Kazakhstan "Kazakhstan in a new reality: a time for action" it is noted: "It is impossible to create a competitive economy without a developed agriculture." The problems of food security today are global in nature. The problems of food production, distribution and trade are the basis of agri-food policy of any state. In recent years, the agricultural sector of Kazakhstan has had positive dynamics, as evidenced by the data of international experts [2].

According to the international rating conducted by the British magazine "The Economist" (results of 2020), Kazakhstan ranked 32nd out of 113 countries in terms of comprehensive indicators of food security (2019 - 48th place). Among the CIS countries, this is the third place after Belarus (23rd place) and Russia (24th place). For the Republic of Kazakhstan, the achieved level in the ranking among developed countries is the result of the sustainable development of the industry in recent years [3].

Methodology. The main research methods are analytical, which allows to study the processes of development of agro-industrial production in dynamics; comparative analysis to determine the level of growth or decrease in production by year, per capita. Included in the analysis is a comparison of actual data with standards, indicators of the effective use of agricultural resources and their role in increasing production volumes, in particular, in the use of land resources; an economic and statistical method. Statistical data for 2000, 2015-2020 were used. according to the production of the main types of agricultural products in Kazakhstan, the population, the level of consumption of products per capita, the availability of agricultural machinery, data on export and import of agricultural products, data on the volume of financing of agricultural science. The causal method reveals the main reasons for the low productivity of agricultural sectors, in particular crop yields: low soil fertility, a significant number of small-scale and small-earth agricultural formations, insufficient development of seed production and lack of agricultural machinery

Results. So, only in 2015-2020 yy. growth by types of agricultural products ranged from $7.5 \%$ to 2.5 times. The production of vegetables (by 28.8\%), oilseeds (by 65.2\%), sugar beet (by 48.9\%), fruits (by 65.6\%), meat (by 25.3\%) has grown especially significantly over the specified period (Table 1). At the same time, the level of 1990 has not been reached for certain types of products (grain, sugar beet, meat), which is a growth potential for the near future.

Table 1. - Production of the main types of agricultural products in Kazakhstan, thousand tons.

\begin{tabular}{|c|c|c|c|c|c|}
\hline \multirow[t]{2}{*}{ Name } & \multicolumn{3}{|c|}{ Actual production } & \multicolumn{2}{|c|}{ 2020y. in \% to: } \\
\hline & 1990y. & $2015 y$. & 2020y. & 1990y. & $2015 y$. \\
\hline Cereals & 28487,0 & 18672,8 & 20065,3 & 70,4 & 107,5 \\
\hline Potato & 2324,0 & 3521,1 & 4006,7 & 172,4 & 113,8 \\
\hline Vegetables & 1136,0 & 3564,9 & 4590,9 & 4,0 times & 128,8 \\
\hline Melon crops & 302,0 & 2087,6 & 2425,0 & 8,0 times & 116,2 \\
\hline Oilseeds & 229,8 & 1547,5 & 2556,5 & 11 times & 165,2 \\
\hline including sunflower & 126,0 & 534,0 & 844,2 & 6,7 times & 158,1 \\
\hline Sugar beet & 1044,0 & 174,1 & 466,3 & 44,7 & 248,9 \\
\hline Fruit & 301,0 & 216,2 & 347,2 & 115,3 & 160,6 \\
\hline Meat & 1559,6 & 931,0 & 1166,6 & 74,8 & 125,3 \\
\hline Milk & 5641,6 & 5122,4 & 6051,4 & 107,3 & 118,1 \\
\hline Egg, million pcs. & 4135,1 & 4736,9 & 5065,8 & 122,5 & 106,9 \\
\hline
\end{tabular}

Note: compiled by the authors. 


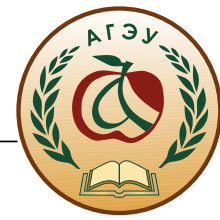

The growth of production in recent years has occurred both due to the economic regulation of the industry and the effective involvement of land resources in agricultural production.

In 2001-2020, the area of farmland increased by 14.4 million hectares as a result of the involvement of reserve lands in agricultural use. Arable land increased by 5.7 million hectares, irrigated arable land - by 300 thousand hectares, pastures - by 13.8 million hectares. The total sown area in the republic in 2020 amounted to 21.8 million hectares, compared with 16.2 million hectares in 2000. In its structure, $70.5 \%$ is occupied by cereals, oilseeds $-11.3 \%$, fodder $-15.5 \%$ [4].

The involvement of additional areas of farmland in economic turnover, the growth of livestock contributed to an increase in agricultural production per capita and improved food security of the country's population, as evidenced by the data in Table 2 .

Table 2. - Production of the main types of agricultural products per capita in Kazakhstan (kg. per capita).

\begin{tabular}{|c|c|c|c|c|c|}
\hline \multirow[t]{2}{*}{ Name } & \multicolumn{3}{|l|}{ Actually } & \multicolumn{2}{|c|}{2020 г. in \% to: } \\
\hline & $1990 y$. & $2015 y$. & $2020 y$. & $1990 y$. & $2015 y$. \\
\hline Seed & 1702,0 & 1072,2 & 1076,9 & 63,3 & 100,4 \\
\hline Potato & 139,0 & 202,2 & 215,0 & 154,7 & 106,3 \\
\hline Vegetables and melons & 86,0 & 324,5 & 376,5 & 4,4 times & 116,0 \\
\hline Oilseeds & 13,7 & 88,8 & 137,2 & 10 times & 154,5 \\
\hline Sugar beet & 62,0 & 10,0 & 25,0 & 40,3 & 250,0 \\
\hline Fruits and berries & 18,0 & 12,4 & 18,6 & 103,3 & 150,0 \\
\hline Meat & 92,0 & 53,4 & 62,6 & 68,0 & 117,2 \\
\hline Milk & 337,0 & 297,6 & 324,8 & 96,4 & 109,2 \\
\hline Egg & 250,0 & 272,0 & 272,0 & 108,8 & 100,0 \\
\hline
\end{tabular}

Note: compiled by the authors.

However, the achieved level of production for certain types of products does not allow the population to consume them according to the standards defined by the Ministry of National Economy of the Republic of Kazakhstan (Table 3).

Table 3. - Food consumption in Kazakhstan (kg. per capita).

Note: compiled by the authors.

\begin{tabular}{|c|c|c|c|c|c|c|c|}
\hline Products & 1990y. & 2016y. & 2020y. & $\begin{array}{l}\text { Ministry of Na- } \\
\text { tional Economy }\end{array}$ & $\begin{array}{l}\text { Consun } \\
\text { standar }\end{array}$ & aption in & $\%$ to the \\
\hline & & & & $\begin{array}{l}\text { of the Republic } \\
\text { of Kazakhstan }\end{array}$ & 1990y. & $2016 y$. & $2020 y$. \\
\hline Bread products and cereals & 148,0 & 130,7 & 140,3 & 109 & 135,8 & 119,9 & 128,7 \\
\hline Potato & 86,0 & 110,9 & 114,3 & 100 & 86,0 & 110,9 & 114,3 \\
\hline Vegetables and melons & 76,0 & 90,2 & 86,6 & 149 & 51,0 & 60,5 & 58,1 \\
\hline Fruit & 23,0 & 64,6 & 63,5 & 132 & 17,4 & 48,9 & 48,1 \\
\hline Vegetable oil & 11,2 & 19,5 & 17,3 & 12 & 93,3 & 162,5 & 147,2 \\
\hline Sugar and confectionery & 38,0 & 40,7 & 43,0 & 33 & 115,2 & 123,3 & 130,3 \\
\hline Meat and meat products & 73,0 & 68,3 & 74,4 & 78,4 & 93,1 & 87,1 & 94,9 \\
\hline Milk and dairy products & 311,0 & 238,9 & 238,6 & 301 & 103,3 & 79,4 & 79,3 \\
\hline Egg & 225,0 & 237,0 & 263,0 & 265 & 84,9 & 89,4 & 99,3 \\
\hline
\end{tabular}




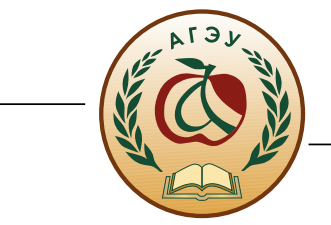

This is especially true for potatoes, vegetables, fruits, milk and eggs. At the same time, bread, vegetable oil, sugar, i.e. glucose-forming products are excessively consumed, which clearly violates the structure of nutrition and leads to excess human weight and various diseases. The level of food security is determined by the share of imported products in the market capacity. The greatest dependence on the external market for: fruits $-67.9 \%$ in the structure of the market capacity, poultry meat $-49.9 \%$, vegetable oil $-39.0 \%$, sugar $-38.9 \%$ (taking into account own production and imported raw materials). In addition, canned products occupy a large share of imports in the market capacity (up to 96\%).

Thus, the share of imports for many products remains high and exceeds the threshold level of $20 \%$ of imports in the capacity of the domestic market.

The capacity of the food market and ensuring food security is also affected by the level of exports of products. In Kazakhstan, the basis of agricultural exports is grain and grain products. In recent years, the export of these products has been at the level of 7-8 million tons. Grain export resources can be significantly higher (up to 10-12 million tons), especially to the countries of Central Asia. However, there are both internal and external problems that hinder exports. Internal problems include: a low level of provision of grain storage capacities (capacities only provide grain storage in years with average yields); insufficient elaboration of the mechanism for regulating the relationship of subjects in the grain market (small and mediumsized grain producers do not have access to the production and logistics infrastructure of grain farming and cannot independently enter the foreign market).

There is also an obvious lack of a unified pricing policy and high domestic prices for Kazakh grain that do not allow the formation of competitive export prices for flour; weak organization of transport logistics for grain transportation (shortage of grain wagons, etc.), high railway tariffs for grain supply; inefficient policy in the field of diversification of sown areas of grain crops.

Along with internal problems in the foreign market, there are factors constraining the export of Kazakh grain and grain products. Currently, there is fierce competition for the markets to which Kazakh wheat is exported: in the countries of Central Asia (Turkmenistan, Kyrgyzstan, Tajikistan, Uzbekistan, Afghanistan), where wheat and flour from Kazakhstan dominated in the volume of their imports, products from other countries (Russia, Pakistan) have now begun to arrive; in Azerbaijan, Kazakh wheat competes with Russian; in Iran - with products from various manufacturing countries, including Canadian, European. In addition, the purchasing countries are introducing various economic measures. Thus, a fierce competition is developing in the foreign wheat market between the EAEU member states and other states [5].

An important place in the export of agricultural products belongs to meat. Today Kazakhstan produces more than 1 million tons of meat and has a great export potential. The land resources of Kazakhstan have real opportunities to double the number of livestock and its productivity. The needs of the livestock market are huge both within the country and in a number of states.

Consequently, the agro-industrial complex of the country, having a huge potential, has a great prospect of development and, accordingly, the possibility of entering foreign markets. The export of agricultural products stimulates the production of domestic raw materials, increases the load of processing enterprises. Well-established export channels can become a factor that, eventually, will raise domestic agriculture and processing to a new level.

In this direction, in recent years, work has been intensified on the development of meat animal husbandry, feed production, expansion of acreage of fodder crops, management of 


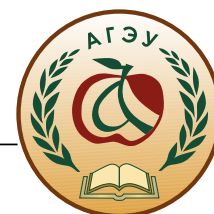

pasture resources, increase of state support measures, improvement of the veterinary organization system and ensuring the safety of livestock products.

Currently, the volume of its financing in Kazakhstan is $0.16 \%$ of gross agricultural output. In accordance with the State Program for the development of agriculture for 20172021 , it is planned to increase the financing of agricultural science in 2030 to $1 \%$ of total agricultural production, including $0.5 \%$ in 2021 . For comparison, in 1991, the amount of funding for the science of the agricultural sector of the republic was $1.2 \%$ of gross agricultural output. Also, according to the recommendations of the International Academic Council, the share of spending on science among developing countries should be about 1-1.5\% of GDP, and in developed countries it is from 2 to $4.5 \%$ of GDP.

The implementation of the above measures, as well as the creation of an innovation and technological system, together with measures of state support, will increase production volumes in the industry to an appropriate level that ensures the country's food security.

Conclusions. The agricultural sector is the leading sector of Kazakhstan's economy, despite the fact that it occupies only $8 \%$ of the GDP structure. But this industry ensures the vital activity of the entire population of the country (19 million people). In the last decade, agro-industrial production has been steadily developing. In 2015-2020, the production of agricultural products increased by $7.5 \%$ to 2.5 times in certain sectors, which ultimately contributed to an increase in the level of food security of the country's population.

At the same time, the achieved level of production does not yet allow for a number of types of food to be consumed according to scientifically sound standards. These products include: potatoes, vegetables and melons, fruits, milk and eggs. For some products, excessive consumption is observed, that is, significantly higher than normal. These include: bread, vegetable oil, sugar, that is, containing a large amount of glucose, which leads to a violation of the quality of the diet and worsens the health of the population.

The level of food security is largely determined by both production volumes, exports of products, and import volumes. There is a close interdependence between these indicators. High production volumes lead to full or close to full provision of food needs. Excess production determines the size of exports, and its insufficient or low level increases the import of imported products to the domestic market of the state, and it becomes import-dependent. In Kazakhstan, export-oriented agricultural products are: grain, flour, certain types of meat (beef, lamb). The rest of the production is focused on the domestic market. In the structure of nutrition, a large share of imports in fruits (67.9\% in the structure of market capacity), poultry meat $(49.9 \%)$, vegetable oil $(39.0 \%)$, sugar $(38.9 \%)$.

Kazakhstan has large amounts of farmland, especially pastures. Currently, there are 100.9 million hectares of farmland in use by agricultural producers, including 19.6 million hectares in the all territories. At the same time, about 90 million hectares of pastures belong to reserve lands, which represent a large reserve for the development of animal husbandry and a 2 -fold increase in meat production for domestic consumption and export.

The successful development of the agricultural sector is largely determined by its material and technical base. Currently, the number of agricultural machinery in Kazakhstan is much lower than the need for it. Compared to 1991. It has decreased by an average of 2.5 times by species, besides its wear, according to experts, is more than $70 \%$. Therefore, for the development of the agricultural sector, it is necessary to take appropriate measures as soon as possible in order to strengthen the technical base of the industry. As world experience shows, service cooperatives should be created in this area, rental, rental and leasing of equipment should be developed. 


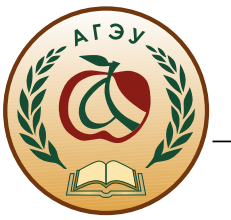

To increase the competitiveness of agricultural production, it is necessary to increase the efficiency of scientific research, to provide scientific institutions with sufficient funding. According to world experience, its level should be at least $1-1.5 \%$ of the value of gross agricultural output.

\section{List of references:}

1. Молдашев, А.Б. (2017). АПК Казахстана: проблемы и пути их решения: монография / А.Б. Молдашев. - Алматы: КазНИИЭАПКиРСТ.- 150 с.

2. Рейтинг стран мира по уровню продовольственной безопасности. Глобальный индекс продовольственной безопасности 2020 [Электронный ресурс]. - 2020. - URL: http:// www.gtmarket.ru/ratings/global-food-security-index (дата обращения: 21.11.2021).

3. Калиев, Г.А. (2019). Продовольственная безопасность Казахстана // В кн.: Стратегия экономической безопасности и социальной стабильности Казахстана / Г.А Калиев, А.Б., Молдашев, Г.А. Никитина.- Алматы: Институт экономики КН МОН РК.C. 343-390.

4. Кешуов, С.А. (2017). Рекомендации по развитию сельскохозяйственного машиностроения Казахстана / С.А. Кешуов, А.С Усманов.- Алматы.- С.23-39.

5. Калиев, Г.А. (2015). Развитие животноводства Казахстана на основе обводнения пастбищ с применением возобновляемых источников энергии: монография / Г.А. Калиев, А.Б. Молдашев, А.И. Сабирова. - Алматы: КазНИИЭАПКиРСТ.- С.18-23.

\section{List of references (транслитерация):}

1. Moldashev, A.B. (2017). APK Kazahstana: problemy i puti ih resheniya: monografiya / A.B. Moldashev. - Almaty: KazNIIEAPKiRST.- 150 p. [in Russian].

2. Rejting stran mira po urovnyu prodovol'stvennoj bezopasnosti. Global'nyj indeks prodovol'stvennoj bezopasnosti 2020 [Elektronnyj resurs]. - 2020. - URL: http:// www.gtmarket.ru/ratings/global-food-security-index (date of access: 21.11.2021). [in Russian].

3. Kaliev, G.A. (2019). Prodovol'stvennaya bezopasnost' Kazahstana // V kn.: Strategiya ekonomicheskoj bezopasnosti i social'noj stabil'nosti Kazahstana / G.A Kaliev, A.B., Moldashev, G.A. Nikitina.- Almaty: Institut ekonomiki KN MON RK.- P. 343-390. [in Russian].

4. Keshuov, S.A. (2017). Rekomendacii po razvitiyu sel'skohozyajstvennogo mashinostroeniya Kazahstana / S.A. Keshuov, A.S Usmanov.- Almaty.- P.23-39. [in Russian].

5. Kaliev, G.A. (2015). Razvitie zhivotnovodstva Kazahstana na osnove obvodneniya pastbishch s primeneniem vozobnovlyaemyh istochnikov energii: monografiya / G.A. Kaliev, A.B. Moldashev, A.I. Sabirova. - Almaty: KazNIIEAPKiRST.- P.18-23. [in Russian].

\section{АЗЫҚ-ТУЛІКПЕН МОЛЫҚТЫРУДЫ ҚАМТАМАСЫЗ ЕТУ ҮШІН АГРАРЛЫҚ НАРЫКТЫ РЕТТЕУ \\ * А. Адельбаева ${ }^{1}$, А. Бекметова ${ }^{2}$ \\ ${ }^{1}$ Абай атындагы Қазақ ұлттық педагогикальқ университеті, Алматы, Қазақстан \\ 2 әл-Фараби атындавы Қазақ ұлттық университеті, Алматы,Қазақсстан \\ *e-mail: derzkiy.maga@mail.ru}

Түйін. Жұмыста елді азық-түлікпен құмтамасыз ету үшін Қазақстан Республикасының аграрлық нарывын жүйелеу мен жетілдірудің негізгі бавыттары қаралды. Мақ̧алада Қазақсстан Республикасының Стратегиялық жоспарлау және реформалар жөніндегі агенттігі Ұлттық статистика бюросының деректері негізінде Санаттар разрядында ұлттық нарықтың азық-түлікпен құамтамасыз етілуіне талдау беріледі. 
Авторлар Қазақсстанның аграрлық секторының қазіргі жай-күйіне, оның проблемаларын анықтаува және жаһандану прочестері жавдайында оны дамыту жөнінде ұсыныстар әзірлеуге өз көзқарасын ұсынады. Жұмыста сауда мен басқа елдермен экономикальқ байланыстардың кеңеюі жавдайында аграрлық секторва сыртқы факторлар көбірек әсер етеді, бұл тұрақсыздықтың өсуіне әкеледі.

Түйін сөздер: агроөнеркәсіптік кемен, экономика, даму, азық-түлік қ̧ауіпсіздігі, өнім сапасы, азық-түлік, ауыл шаруашыльвыл.

\section{РЕГУЛИРОВАНИЕ АГРАРНОГО РЫНКА ДЛЯ ОБЕСПЕЧЕНИЯ ПРОДО- ВОЛЬСТВЕННОГО НАСЫЩЕНИЯ \\ * А. Адельбаева ${ }^{1}$, А. Бекметова ${ }^{2}$ \\ ${ }^{1}$ Казахский национальный педагогический университет имени Абая, Алматы, Қазақсттан \\ ${ }^{2}$ Казахский национальный университет им. аль-Фараби. Алматы, Қазақсттан \\ *e-mail: derzkiy.maga@mail.ru}

Резюме. В работе рассмотрены основные направления систематизации и совершенствования аграрного рынка Республики Казахстан для продовольственного обеспечения страны. В статье даётся анализ обеспеченности национального рынка продовольствием в разряде категорий на основе данных Бюро национальной статистики Агентства по стратегическому планированию и реформам Республики Казахстан. Авторами предлагается свое видение на современное состояние аграрного сектора Казахстана, выявление его проблем и разработка предложений по его развитию в условиях глобализационных прочессов. В работе охарактеризовано то, что в условиях расширения торговли и экономических связей с другими странами аграрный сектор все больше подвергается влиянию внешних факторов, что ведет к росту нестабильности.

Ключевые слова: агропромышленный комплекс, экономика, развитие, продовольственная безопасность, качество продукиии, продовольствие, сельское хозяйство.

Адельбаева Айман Канатовна

Докторант Казахского национального педагогического университета имени Абая.

Бекметова Аруна Кернеевна

Старший преподаватель кафедры «Бизнес-технологий», Магистр экономики и бизнеса, Казахский национальный университет им. аль-Фараби.

Адельбаева Айман Канатовна

Абай атындагы Қазақ ұлттық педагогикалық университетінің, докторанты.

Бекметова Аруна Кернеевна

«Бизнес-технологиялар» кафедрасының ава оқытушы, Экономика және бизнес магистрі, әлФараби атындавы Қазақ ұлттық университеті.

Adelbaeva Aiman Kanatovna

Phd student of the Kazakh National Pedagogical University named after Abay.

Bekmetova Aruna Kerneevna

Senior lecturer of the Department of «Business Technologies», Master of economics and business, Kazakh National University named after al-Farabi. 


\section{ПРАВИЛА ДЛЯ АВТОРОВ ЖУРНАЛА}

(с учетом изменений в Требованиях к научным изданиям для включения их в Перечень изданий, рекомендуемых для публикации результатов научной деятельности-Приказ Министра образования и науки Республики Казахстан от 30 апреля 2020 года № 170)

Журнал «Статистика, учет и аудит» (в дальнейшем - Журнал) публикует оригинальные работы ученых и специалистов научно-исследовательских организаций, высших учебных заведений, организаций и административных структур Казахстана, а также иностранных авторов. В журнале публикуются оригинальные статьи по научным направлениям статистики, учета и аудита, микро и макроэкономические вопросы международной и отечественной экономики, финансов, информатики и педагогики. Также публикуются рецензии, хроники научной жизни и др. материалы, имеющие отношение к деятельности Учредителя журнала.

Обязательными условиями для публикации являются:

1.Соответствие публикуемых научных статей (в том числе обзоров) заявленной цели и тематическому направлению журнала. Научная статья - изложение собственных выводов и промежуточных или окончательных результатов научного исследования, экспериментальной или аналитической деятельности, содержащее авторские разработки, выводы, рекомендаций ранее не опубликованные и обладающие новизной; или посвященное рассмотрению ранее опубликованных научных статей, связанных общей темой (систематический обзор).

2.Структура научной статьи включает название, аннотацию, ключевые слова, основные положения, введение, материаль и методы, результаты, обсуждение, заключение, информацию о финансировании (при наличии), список литературы. В каждой оригинальной статье (за исключением социально-гуманитарного направления) обеспечивается воспроизводимость результатов исследования, описывается методология исследования с указанием происхождения оборудования и материалов, методов статистической обработки данных и других способов обеспечения воспроизводимости. Содержание других типов публикаций не превышает 10\% (десять) от общего количества статей в номере. При этом автор или коллектив авторов вносят значительный вклад в концепцию, научный дизайн, исполнение или интерпретацию заявленного научного исследования и создание научной статьи. Наличие библиографической информации - заголовка статьи, аннотации, ключевых слов, информации об авторах на английском языке обязательно.

2.1 В аннотации (аңдатпа, abstract) публикуемой статьи на языке статьи излагаются суть и использованные методы исследования, суммируются наиболее важные результаты и их значимость. Объем аннотации составляет не более 300 слов (минимальный объем-100 слов). 


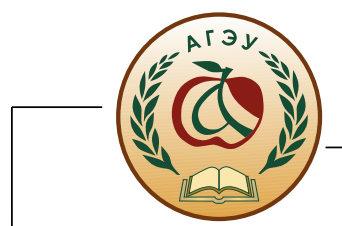

2.2 Резюме (түйін, summary) на двух не на языке статьи (казахском, русском и английском) языках. Например, резюме и summary- это не переводы аңдатпа, а краткое изложение о статье на русском и английском языках (если статья написана на казахском) и рекомендуется их приводить после списка литературы.

2.3 Ключевые слова (түйінді сөздер, key words) предназначены для поиска текста статьи и определения ее предметной области. Например, они приводятся после аннотации (если статья написана на русском) и двух резюме (түйін, summary). Ключевые слова должны обеспечить наиболее полное раскрытие содержания статьи.

2.4 Информация об авторах - имена (Фамилия И.О. авторов), аффилиации (полное название учреждения, которое представляет автор (авторы), название страны, и адреса всех авторов публикаций, в том числе с указанием основного автора-выделить звездочкой (*), е-таil (основного автора).

3. Список литературы. Ссылки на источники в тексте статьи даются только в квадратных скобках (без цитирования [12], при цитировании или пересказе авторского текста [12, с. 29]). Используемая литература, указываемая в ссылках, дается в конце статьи пронумерованной и в порядке упоминания по авторам. Архивные материалы в список не включаются, ссылки на них помещаются в тексте в круглых скобках. При использовании в статье: источников законодательных, нормативно-правовых актовссылки на них делать в тексте сразу же после них, а источников из электронных ресурсов или удаленного доступа (Интернета) в списке литературы приводится библиографическая запись источника и ссылка на сетевой ресурс с полным сетевым адресом в Интернете. Желательно указывать дату обращения к ресурсу. Список литературы предоставляется на языке оригинала и должен состоять не более чем из 20 наименований.

3.1 Наличие транслитерированных списков литературы (используемых источников) к каждой статье. Существуют различные системы транслитераций. Предложение редакции по транслитерации (вы имеете право найти другой способ):

3.1. На данной странице Вы можете выполнить транслит - онлайн русских букв латиницей:

Транслитерация с русского на английский онлайн

https://lim-english.com/posts/transliteratsiya-s-russkogo-na-angliiskij/

4. Ответственность за содержание статей несут авторы.

5. Этические принципы, которыми должен руководствоваться автор научной публикации. Представление статьи на рассмотрение в редакцию подразумевает, что она содержит полученные автором (коллективом авторов) новые научные результаты, которые ранее нигде не публиковались. Автор должен осознавать, что несет персональную ответственность за представляемый текст рукописи. Это предполагает соблюдение следующих принципов:

5.1. Автор статьи гарантирует, что предоставляет редакции журнала достоверные результаты выполненной научной работы или исследования. Заведомо ложные или 
сфальсифицированные утверждения приравниваются к неэтичному поведению и являются неприемлемыми.

5.2. В случае, если главный редактор журнала запрашивает у автора научной статьи ее исходные данные для рецензирования, автор, если это возможно, должен быть готов предоставить открытый доступ к таким данным; автор также берет на себя обязательство сохранять исходные материалы статьи в течение разумного периода, прошедшего после ее публикации.

5.3. Автор гарантирует, что результаты исследования, изложенные в рукописи, представляют собой самостоятельную и оригинальную работу. В случае использования фрагментов чужих работ или заимствования утверждений других авторов, в статье должны быть оформлены соответствующие библиографические ссылки с обязательным указанием автора и первоисточника. Все статьи проходят обязательную проверку через систему «Антиплагиат». Все статьи проверяются на предмет обнаружения плагиата (оригинальность должна быть не менее 70\%). Применяется лицензионная программа АНТИПЛАГИАТ.ВУЗ Договор № 1065 от 29 декабря 2020 г.) Чрезмерные заимствования, а также плагиат в любых формах, включая неоформленные цитаты, перефразирование или присвоение прав на результаты чужих исследований, являются неэтичными и неприемлемыми действиями. Статьи, представляющие собой компиляции из материалов, ранее опубликованных другими авторами, без их творческой переработки и собственного авторского осмысления, редакцией журнала к публикации не принимаются.

5.4. Автор безусловно признает вклад всех лиц, так или иначе повлиявших на ход исследования или определивших характер представленной научной работы. В частности, в статье должны быть сделаны библиографические ссылки на отечественные и зарубежные публикации, которые имели значение при проведении исследования. Информация, полученная в частном порядке путем разговора, переписки или обсуждения с третьими лицами, не должна использоваться без получения открытого письменного разрешения от ее источника. Все источники должны быть раскрыты. Даже в том случае, если используемые в статье письменные или иллюстративные материалы получены от большого числа людей, автору статьи необходимо представить в редакцию все соответствующие разрешения на использование этих материалов.

5.5. Автор гарантирует, что представленная в журнал рукопись статьи не находится на рассмотрении редакции другого научного журнала и не была ранее опубликована в другом журнале. Несоблюдение этого принципа расценивается как грубое нарушение этики публикаций и дает основание для снятия статьи с рецензирования. Текст статьи должен быть оригинальным, то есть публиковаться в представленном виде в периодическом печатном издании впервые. Если элементы рукописи ранее были опубликованы в другой статье, автор обязан сослаться на более раннюю работу и указать, в чем состоит существенное отличие новой работы от предыдущей. Дословное копирование собственных работ и их перефразирование неприемлемы, они могут быть использованы только как основа для новых выводов. 


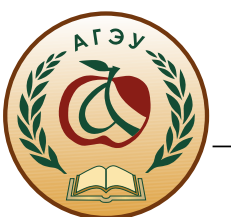

5.6. Автор статьи гарантирует правильность списка соавторов. В числе соавторов должны быть указаны все лица, внесшие существенный интеллектуальный вклад в концепцию, структуру, а также в проведение или интерпретацию результатов представленной работы. Другим лицам, чье участие в представленной в журнал работе ограничилось некоторыми ее аспектами, должна быть выражена благодарность. Автор статьи должен также гарантировать, что все соавторы ознакомлены с окончательным вариантом статьи, одобрили его и согласны с ее представлением к публикации. Все указанные в статье соавторы несут совокупную ответственность за ее содержание. Если статья является мультидисциплинарной работой, соавторы могут также принимать на себя ответственность за свой личный вклад в работу, продолжая при этом нести коллективную ответственность за результат исследования в целом. Недопустимо указание в качестве соавторов статьи лиц, не принимавших участия в исследовании.

5.7. В случае обнаружения существенных ошибок или неточностей в статье на этапе ее рассмотрения или после ее опубликования автор обязан незамедлительно уведомить об этом редакцию журнала и принять совместное решение о признании ошибки и/или ее исправлении в максимально короткие сроки. Если редакция узнает от третьего лица, что опубликованная работа содержит существенные ошибки, автор обязан незамедлительно исправить их либо предоставить редакции доказательства правильности ранее предоставленной им информации.

5.8. Автор обязуется указывать в своих рукописях все источники финансирования работы, заявлять о возможных конфликтах интересов, которые могут повлиять на результаты исследования, их интерпретацию, а также на суждения рецензентов. Потенциальные конфликты интересов должны быть раскрыты как можно раньше.

6. Поступившие от авторов научные статьи проходят первичный контроль на комплектность и правильность оформления. Далее статья направляется на предмет обнаружения плагиата (оригинальность должна быть не менее 70\%). Применяется лицензионная программа АНТИПЛАГИАТ.ВУЗ Договор № 1065 от 29 декабря 2020 г.), после чего, научные статьи, поступившие в редакцию, проходят обязательное слепое рецензирование порядок прохождения, которых описан в разделе Рецензирование.

При отрицательном отзыве рецензентов редакция Журнала обязуется сообщать авторам все комментарии об их работе, сделанные рецензентами, если только они не содержат обидные или клеветнические замечания.

7. В конце статьи предоставляются заполненные формы для размещения сборника статей в Научной электронной библиотеке (eLibrary.ru) и включения сборника статей в Российский индекс научного цитирования (РИНЦ):

\section{ФОРМА}

для размещения сборника статей в Научной электронной библиотеке (eLibrary.ru) и включения сборника статей в Российский индекс научного цитирования (РИНЦ)

1. Название статьи: на казахском, русском и английском языках 
2. Сведения об авторе (авторах):

- фамилия, имя, отчество (полностью) автора (авторов) с указанием ученой степени и ученого звания (при наличии) на трех языках:

- место работы автора (авторов) (должность и организация) на трех языках:

- контактная информация:

e-mail автора (авторов) - тел.номер автора (авторов) -

8. Редакция оставляет за собой право редакторской правки.

Технические требования

1. Общий объем статьи, включая аннотацию, ключевые слова, литературу, таблицы и рисунки не должен превышать 6-8 страниц. Исключение составляют заказные и обзорные статьи.

2. Статьи должны быть оформлены в строгом соответствии шрифтом гарнитуры Times New Roman.

МРНТИ

\section{Схематический пример оформления статьи}

УДК 339.74

DOI (Digital Object Identifier) xxxxxxxxxx

По центру приводятся: Название статьи

(Поля: сверху - 2 см., слева-3 см., справа -1,5 см. Шрифт полужирный. Кегль-14 пт, межстрочный интервал - одинарный.)

Фамилии и инициалы авторов (напр.И.В.Иванов, Ю.П.Крылов)

Полное название учреждения, которое представляе(ю)т автор(ы) с указанием города и страны, электронного адреса основного автора выделением надстрочной звездочкой. Если авторы из разных учреждений, то соответствие между автором и учреждением устанавливается надстрочными индексами, например:

\section{${ }^{*}$ И.В. Иванов ${ }^{1}$, Ю.П. Крылов ${ }^{2}$}

${ }^{1}$ Алматинский гуманитарно-экономический университет, Алматы, Казахстан 2 Международная академия бизнеса, Алматы, Казахстан e-mail: ivanov@mail.ru

- Аннотация.

- Ключевые слова.

- Текст статьи: Поля: сверху, снизу - 2 см., слева - 3 см., справа -1,5 см. Шрифт Times New Roman. Кегль-14 пт. Абзацный отступ-1,25 см., межстрочный интервал одинарный).

- Список литературы. Транслитерированный список литературы (References)

- После списка литературы приводятся:

Название статьи перед каждым резюме на двух не на языке статьи (казахском, русском и английском) языках. 
ISSN 1563-2415

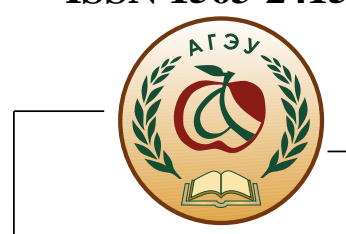

После каждого названия статьи приводятся см. выше (последовательно) пп. 2.4, 2.2, 2.3 Руководства для авторов

3. Таблицы и рисунки с названиями должны быть пронумерованы по порядку (если их несколько). Нумерация таблицы (Таблица 1.) должна быть расположена вверху слева выше названия таблицы через абзацный отступ.

4. Рисунки, фотографии, таблицы должны быть четкими и контрастнымив формате jpg, иметь разрешение не менее 300 dpi, подрисуночные надписи к ним должны быть расположены ниже рисунка по центру. Цветные рисунки, диаграммы не допускаются.

5. На рисунках должен быть минимум буквенных и цифровых обозначений, обязательно объясненных в статье или подрисуночных подписях.

6. Необъясненные сокращения слов, имен, названий, кроме общепринятых, не допускаются. Аббревиатуры расшифровываются после первого появления в тексте, например: Организация по экономическому сотрудничеству и развитию (ОЭСР).

7. Упомянутые в статьях единицы измерения должны соответствовать Международной системе единиц СИ.

8. Математические формулы должны быть набраны в Microsoft Education (каждая формула - один объект). Нумеровать следует лишь те формулы, на которые имеются ссылки.

9. Редакция не занимается литературной и стилистической обработкой статей. Материалы, статьи не возвращаются

10. Авторам для рассмотрения статьи необходимо представить рукопись на сайт www.sua.aesa.kz, и копию статьи со всеми сопроводительными документами согласно требованию направить на e-mail: zhurnal.aesa.99@ mail.ru :

10.1. Электронную версию статьи;

10.2.Наукометрическую базу данных для РИНЦ

10.3. Представить сканированную копию квитанцию об оплате за публикацию статьи и квитанцию об оплате за присвоение DOI (Digital Object Identifier) авторам, (только после подтверждения редакцией Журнала статьи к опубликованию).

ВНИМАНИЕ: DОI (Digital Object Identifier) присваивается регистрационным агентством International DOI Foundation (Интернэйщенел ДОИ Фаундэйщен). 